\title{
Pengelolaan Sampah Secara Terpadu Berbasis Lingkungan Masyarakat Di Desa Rumbuk
}

Muhammad Rapii ${ }^{1}$, Muhammad Zainul Majdi², Rohaeniah Zain ${ }^{3}$, Qurratul Aini $^{4}$

${ }^{1234}$ Universitas Hamzanwadi.

Email: mrapii166@gmail.com

\begin{tabular}{ll}
\hline Article History: & Abstrak: \\
Received: & Peningkatan volume sampah di luar \\
Revised: & kemampuan kapasitas tempat pembuangan \\
Accepted: & sampah untuk menampung seluruh sampah di \\
Available online: & Desa Rumbuk. Kegiatan ini bertujuan untuk \\
& meningkatkan kesadaran dan partisipasi \\
& masyarakat dalam mengelola sampah. Oleh \\
Kata Kunci: & karena itu, diperlukan upaya yang intensif dan \\
Lingkungan, Pengelolaan & berkelanjutan untuk mengunggah kepedulian \\
Sampah, Sampah & masyarakat terhadap pengelolaan sampah di \\
& lingkungannya. Pengenalan dan penerapan \\
& prinsip 3R (Reduce, Reuse, Recycle) atau \\
& pengurangan, penggunaan kembali dan daur \\
& ulang sampah merupakan salah satu cara \\
& pendekatan sumber dalam pengelolaan \\
& sampah. Dengan konsep ini masyarakat tidak \\
& hanya membuang sampah tetapi juga \\
& memanfaatkannya dan dapat memiliki nilai \\
& tambah. Hasil kegiatan menunjukkan \\
& peningkatan rata-rata pengetahuan masyarakat \\
& sebesar 50,2\% dari seluruh komponen. Namun \\
besarnya peningkatan persentase pengetahuan & tersebut tidak sebanding dengan kenyataan di \\
lapangan, yang menunjukkan bahwa masih & sangat sedikit masyarakat yang berkiprah \\
dalam pengelolaan sampah secara mandiri.
\end{tabular}




\section{Pendahuluan}

Permasalahan sampah telah menjadi permasalahan serius di berbagai tempat di Indonesia. Semakin meningkatnya jumlah dan aktivitas penduduk yang tidak diimbangi dengan perbaikan serta peningkatan kapasitas sistem pengelolaan sampah di berbagai daerah telah menyebabkan menumpuknya sampah di berbagai tempat yang tidak semestinya. Sampah-sampah yang tidak terkelola dengan baik tersebut dapat menjadi sumber penyakit dan menyebabkan berkurangnya keindahan serta kenyaman lingkungan di sekitarnya.

Berdasarkan hasil Observasi, diperoleh informasi bahwa warga desa tidak memiliki tempat sampah untuk melakukan proses pewadahan sehingga warga terbiasa membuang sampah sembarangan dan membakarnya di sekitar rumah. Hal ini menyebabkan sulitnya pengaplikasian pemilahan sampah. Karena tidak adanya tempat pembuangan sampah sementara, maka warga membuang sampah rumah tangga yang berskala besar di lahan kosong atau tambak yang dimanfaatkan menjadi tempat pembuangan akhir. Minim dan mahalnya lahan menyebabkan Desa Rumbuk tidak memiliki tempat untuk pembuangan akhir. Susahnya akses keluar masuk desa membuat warga kesulitan membawa sampah ke tempat pembuangan akhir. Kesadaran masyarakat akan kebersihan lingkungan masih kurang sehingga permasalahan sampah tersebut masih dipandang wajar.

Beberapa faktor yang mempengaruhi pengolahan sampah yang dianggap sebagai penghambat sistem adalah penyebaran dan kepadatan penduduk, sosial ekonomi dan karakteristik lingkungan fisik, sikap, perilaku serta budaya yang ada di masyarakat. Berdasarkan Peraturan Menteri Pekerjaan Umum Republik Indonesia nomor 3 tahun 2013, tempat penampungan sementara (TPS) adalah tempat dimana sebelum sampah diangkut untuk dilakukan pendauran ulang, pengolahan dan tempat pengolahan sampah terpadu. Tempat pengolahan sampah terpadu (TPST) adalah tempat pelaksanaan kegiatan pengumpulan, pemilahan, penggunaan ulang, pendauran ulang, pengolahan dan pemrosesan akhir.

Peran serta masyarakat dalam pengelolaan sampah merupakan kesediaan masyarakat untuk membantu berhasilnya program pengembangan pengelolaan sampah sesuai dengan kemampuan setiap orang tanpa berarti 
mengorbankan kepentingan diri sendiri. Tanpa adanya Peran serta masyarakat semua program pengelolaan persampahan yang direncanakan akan sia-sia. Salah satu pendekatan masyarakat untuk dapat membantu program pemerintah dalam keberhasilan adalah membiasakan masyarakat pada tingkah laku yang sesuai dengan program persampahan yaitu merubah persepsi masyarakat terhadap pengelolaan sampah yang tertib, lancar dan merata, merubah kebiasaan masyarakat dalam pengelolaan sampah yang kurang baik dan faktor-faktor sosial, struktur dan budaya setempat(Affandy et al., 2015)

Tipologi peran serta masyarakat yang dapat dilihat sebagai proses peran serta masyarakat, yaitu sebagai berikut: (1) manipulation, manipulasi adalah tingkatan peran serta masyarakat yang paling rendah. Pada tingkatan ini masyarakat hanya ditempatkan sebagai anggota dan hanya dijadikan alat publikasi dari pihak penguasa. (2) therapy, kegiatan-kegiatan yang dilakukan pada tahap ini hanyalah usaha untuk mengubah pola pikir masyarakat, bukan untuk mendapatkan saran dan masukan dalam membuat program-program pengembangan. (3) informing, tahap ini merupakan tahap awal komunikasi dengan masyarakat, yaitu memberikan pengetahuan mengenai hakhak,tanggung jawab dan pilihan yang dapat diambil oleh masyarakat untuk mengembangkan diri. (4) consultation, langkah ini merupakan tahapan yang penting dilakukan dalam mencapai komunikasi dua arah dengan masyarakat, di mana masukan-masukan dari masyarakat menjadi ide program untuk pengembangan. (5) placation, penunjukkan beberapa masyarakat yang berpengaruh dalam lingkungannya untuk menjadi badan kerja. Sistem ini memungkinkan usulanusulan masyarakat dapat dikemukakan dengan baik melalui perwakilannya. (6) partnership, adanya pembagian kekuasaan antara masyarakat dengan penginisiasi program. Keduanya menyepakati untuk saling berbagi tanggung jawab baik dalam proses perencanaan hingga pemecahan persoalan. (7) delegated power, pada tahap ini masyarakat diberikan kewenangan untuk membuat keputusan/program sesuai dengan kebutuhannya. Masyarakat memiliki kewenangan penuh untuk membuat programprogram pembangunan. (8) citizen control, pada tahap ini masyarakat dapat mengatur program, kelembagaan, dan kendali untuk kepentingan masyarakat itu sendiri. Masyarakat memiliki kewenangan penuh dalam pemegang dana (Olivia et al., 2019). 
Sampah dapat dimaknai sebagai bahan padat sisa proses industri atau sebagai hasil sampingan kegiatan rumah tangga (Sandika. et al., 2018). Undang-Undang No 18 tahun 2008 tentang pengelolaan sampah beserta Peraturan Pemerintah No 81 tahun 2012 mengamanatkan perlunya perubahan paradigma yang mendasar dalam pengelolaan sampah yaitu dari paradigma kumpul-angkut-buang menjadi pengolahan yang bertumpu pada pengurangan sampah dan penanganan sampah (Surya. \& Ariefahnoor., 2018).

Dengan kegiatan ini diharapkan masyarakat akan merubah paradigmanya tentang sampah dan melakukan pengelolaan sampah dengan konsep 3R serta menjadi pelopor pengelolaan sampah berbasis partisipasi aktif dari masyarakat sehingga perkembangan ekonomi tidak akan mengakibatkan dampak negatif yang merugikan masyarakat. Selain itu diharapkan akan terbentuk satu kawasan dengan tingkat pengelolaan sampah mandiri yang akan membantu pemerintah untuk menciptakan lingkungan yang sehat, bersih dan nyaman.

\section{Metode}

Kegiatan pengabdian ini dilakukan dalam dua tahap yaitu tahap pertama penyuluhan dan dilanjutkan dengan terjun langsung pada warga sekitar guna meningkatkan kemampuan warga. Pada tahap pertama dilakukan dengan metode ceramah, diskusi dan tanya jawab. Pada tahap kedua penyuluh terjun langsung ke warga meninjau keseharian warga serta memberikan pengarahan yang tepat guna menuju desa mandiri dan mampu meningkatkan ekonomi masyarakat.Langkah-langkah dalam kegiatan pengabdian ini meliputi (Sandika. et al., 2018), yaitu: (a) tahap persiapan, (b) tahap pelaksanaan dengan metode ceramah, demonstrasi, dikusi; dan (c) evaluasi. Evaluasi dilakukan untuk mengetahui tingkat minat atau perhatian peserta pada pelaksanaan kegiatan. Evaluasi kegiatan dilakukan dengan mengadakan pretest dan post-test untuk membandingkan beberapa parameter ukur yang yang meliputi tentang peningkatan minat, pengetahuan, kemampuan, kesadaran, dan ketrampilan peserta untuk mengolah sampah berdasarkan konsep 3R (Bukhari. \& Afrian., 2020). 


\section{Hasil}

Adapun garis besar hasil pelaksanaan kegiatan PPM adalah sebagai berikut: (1) langkah awal kegiatan PPM, yaitu penyampaian gagasan pelaksanaan pengabdian kepada masyarakat berjalan lancar, (2) Hasil pelaksanaan pelatihan pengelolaan sampah sercara terpadu berbasis lingkungan masyarakat, yaitu sebagai berikut:

a. Materi pelatihan dapat semuanya disampaikan oleh tim Prodi Ekonomi, meskipun tidak disampaikan secara detil.

b. Kemampuan peserta pelatihan dalam penguasaan materi pengelolaan sampah rumah berbasis lingkungan masyarakat masih kurang karena waktu yang terbatas, namun setidaknya ada peningkatan pengetahuan dari yang dulunya tidak tahu menjadi tahu.

c. Program pengabdian berhasil memberdayakan masyarakat untuk mengolah sampah dihasilkan dari rumah tangga.

Pemberdayaan masyarakat dalam pengolahan sampah berdasarkan analisis tingkat partisipatif yang sudah dilakukan sebelumnya. Pembinaan masyarakat diarahkan berdasarkan pendekatan sosial, teknis, dan ekonomi yang merupakan sistem penanganan sampah yang direncanakan, disusun, dioperasikan, dikelola dan dimiliki oleh masyarakat.

Hasil kegiatan PPM secara garis besar dapat dilihat berdasarkan beberapa komponen berikut:

1) Keberhasilan target jumlah peserta pelatihan dapat dikatakan sangat baik, mengingat target jumlah peserta pelatihan sebanyak 30 orang dan dalam pelaksanaan kegiatan dapat hadir sebanyak 30 orang (100\%). Hal ini didukung peran Kepala Desa mulai dari persiapan, penyebaran undangan, pengadaan konsumsi, tempat dan peralatannya.

2) Ketercapaian tujuan pelatihan dapat dikatakan baik (80\%), hal ini dikarenakan adanya peningkatan pengetahuan dari peserta, setidaknya dari yang dulunya tidak tahu menjadi tahu dan kegiatan pengabdian ini berhasil memberdayakan perempuan di Desa Rumbuk Kecamatan Sakra untuk mengolah sampah organik yang dihasilkan dari rumah tangga menjadi kompos dengan metode komposting. 
3) Ketercapaian target materi yang telah direncanakan pada kegiatan PPM ini dapat dikatakan baik (80\%), karena materi pelatihan dapat disampaikan secara keseluruhan meskipun tidak secara detil karena keterbatasan waktu. Materi pelatihan yang telah disampaikan adalah konsep lingkungan hidup, klasifikasi sampah, peran serta perempuan dalam lingkungan hidup, dan pengelolaan sampah rumah tangga dengan metode komposting.

4) Kemampuan peserta dalam penguasaan materi dapat dikatakan cukup (70\%), hal ini dikarenakan waktu yang terbatas dalam penyampaian materi dengan menggunakan metode ceramah dan demonstrasi serta didukung kemampuan para peserta yang berbeda dalam menyerap materi yang disampaikan.

Tabel 1. Arah Pemberdayaan Masyarakat

\begin{tabular}{|c|c|}
\hline Pendekatan & Arahan \\
\hline Pendekatan sosial & $\begin{array}{l}\text { 1. Peningkatan kepedulian, kesadaran, dan tanggung } \\
\text { jawab bersama untuk memilah sampah organik } \\
\text { dan non organik. } \\
\text { 2. Pendekatan kepada pemuka masyarakat setempat } \\
\text { dan izin dari lurah ataupun ketua RT/RW. } \\
\text { 3. Pendekatan kepada warga yang mempunyai } \\
\text { kemauan, kepedulian dan kemampuan dapat } \\
\text { menjadi penggerak masyarakat. } \\
\text { 4. Untuk memperlihatkan manfaat dari TPST bisa } \\
\text { dilakukan dengan studi banding. }\end{array}$ \\
\hline Pendekatan teknis & $\begin{array}{l}\text { 1. Pembentukan komite lingkungan. } \\
\text { 2. Rencana kerja, dan kesepakatan kontribusi } \\
\text { warga. } \\
\text { 3. Melakukan pelatihan daur ulang } \\
\text { 4. Membina serta mendorong masyarakat untuk } \\
\text { membangun dan memelihara fasilitas pengolahan } \\
\text { sampah } \\
\text { 5. Pendampingan, sosialisasi, penyebaran informasi } \\
\text { dan pemantauan penghijauan, dan tanaman } \\
\text { produktif terus menerus sampai menghasilkan } \\
\text { kompos, produk daur ulang, kurangi, pakai ulang, } \\
\text { daur ulang) }\end{array}$ \\
\hline Pendekatan ekonomi & $\begin{array}{l}\text { 1. Memperkenalkan jenis-jenis sampah yang dapat } \\
\text { diolah. }\end{array}$ \\
\hline
\end{tabular}


2. Melakukan penilaian kelayakan ekonomi dari TPST berbasis masyarakat

Program pengabdian berupa pelatihan pengelolaan sampah rumah tangga dengan metode komposting perlu terus diupayakan mengingat produksi sampah rumah tangga yang semakin banyak. Hal ini dipicu dengan rendahnya kesadaran 3R, yaitu reuse (memakai kembali barang bekas yang masih bisa dipakai), reduce (berusaha mengurangi sampah), dan recycle (mendaur ulang sampah agar dapat dimanfaatkan)(Dwiyanto, 2011). Melihat kondisi ini menjadi pertimbangan untuk mencari cara yang tepat dalam mengelola sampah sehingga tidak mencemari lingkungan dan mampu memberikan keuntungan nyata bagi masyarakat (produktif). Dalam rangka mencari penyelesaian masalah sampah secara tepat, maka pada kegiatan pengabdian ini dilakukan pelatihan pengelolaan sampah organik menjadi kompos menggunakan keranjang komposting guna mengatasi keberadaan sampah organik pada tingkat rumah tangga.

Pertama, menyiapkan keranjang Takakura Keranjang yang berlubang tersebut sekelilingnya (bagian dalam) dilapisi kertas kardus, di bagian bawah kemudian diberi sekam yang sudah dijahit seperti bantal dengan karung goni bekas, baru kemudian dimasukkan kompos. Kompaster singkatan dari Komunitas Pengelola Sampah Terpadu(Muryani et al., 2020).

Kedua, Cara memasukkan sampah organik tersebut adalah: (a) timbunan kompos dalam keranjang digali sehingga terbentuk lubang. Besar lubang tergantung jumlah sampah yang dimasukkan. (b) masukkan sampah rumah tangga ke dalam lubang tersebut (akan lebih baik jika sampah dicacah kecil-kecil terlebih dahulu dan umurnya tidak lebih dari 1 hari). (c) sampah tersebut kemudian ditimbun dengan kompos yang ada di sekelilingnya. (d) setelah tertimbun rata kemudian tutup dengan bantal sekam yang tujuannya untuk menyaring gas-gas hasil dekomposisi. (e) kemudian tutup dengan kain agar lalat tidak dapat bertelur yang nantinya dapat menimbulkan belatung serta mencegah proses metamorfosis belatung menjadi lalat. (f) jika keranjang sudah penuh, hanya $1 / 3$ bagian yang bisa diambil untuk dimatangkan selama kurang lebih 1 bulan, dan sisa kompos dalam keranjang bisa dimanfaatkan lagi. Dalam pelaksanaan pengelolaan sampah rumah tangga dengan metode 
komposting, cara kerjanya setelah pemberian materi dilakukan pendampingan terhadap para peserta oleh nara sumber.

Secara keseluruhan kegiatan pelatihan pengelolaan sampah rumah tangga dinilai berhasil. Keberhasilan ini selain diukur dari keempat komponen di atas, juga dapat dilihat dari kepuasan peserta setelah mengikuti kegiatan pelatihan. Manfaat yang dapat diperoleh para peserta pelatihan adalah memahami pengelolaan sampah rumah tangga sehingga dapat turut serta dalam menjaga kelestarian lingkungan.

\section{Dikusi}

Kegiatan dilakukan untuk meningkatkan pengetahuan dan menumbuhkan kesadaran masyarakat tentang pentingnya pengelolaan sampah di lingkungan masing-masing secara mandiri. Selama ini semua warga hanya berpartisipasi dalam pengelolaan sampah dengan membayar iuran sampah dan menyerahkan sepenuhnya pengelolaan sampah pada petugas sampah dan pemerintah kota yang akan mengangkut semua sampah rumah tangga ke TPA. Padahal meningkatnya jumlah penduduk dan perekonomian seiring dengan meningkatnya barang yang dibeli, yang berarti semakin meningkatnya sampah yang dihasilkan. Beberapa sampah yang seperti plastik yang tidak bisa atau lama diuraikan menjadi semakin bertambah dan lama kelamaan sampahsampah tersebut akan menumpuk. Pengelolaan sampah plastik selama ini hanya dibakar, sementara pembakaran sampah plastik ini justru akan membuat permasalahan baru karena munculnya zat yang lebih beracun setelah sampah plastik dibakar.

Dari hasil kegiatan ini dapat dilihat partisipasi peserta untuk mengelola sampah mereka agar lingkungan yang sehat, asri, bebas sampah dapat terwujud. Data menunjukkan bahwa pencapaian kegiatan menunjukkan kecenderungan meningkat dengan prosentase peningkatannya seperti pada Tabel berikut.

Tabel 2. Hasil Pencapaian Kegiatan

\begin{tabular}{lccc}
\hline \multirow{2}{*}{ Indikator } & \multicolumn{3}{c}{ Pencapaian (\%) } \\
\cline { 2 - 4 } & Pretes & Postes & Peningkatan \\
\hline $\begin{array}{l}\text { Pengetahuan umum peserta tentang } \\
\text { sampah dan permasalahannya }\end{array}$ & 53 & 97 & 44 \\
\hline Pengetahuan peserta tentang jenis sampah & 67 & 95 & 28 \\
\hline
\end{tabular}




\begin{tabular}{lccc}
\hline $\begin{array}{l}\text { Pengetahuan peserta tentang sampah } \\
\text { organik dan anorganik }\end{array}$ & 32 & 87 & 55 \\
\hline $\begin{array}{l}\text { Pengetahuan peserta tentang pengelolaan } \\
\text { sampah berdasarkan 3R }\end{array}$ & 18 & 83 & 65 \\
\hline $\begin{array}{l}\text { Pengetahuan dan keterampilan peserta } \\
\text { mengolah sampah }\end{array}$ & 26 & 85 & 59 \\
\hline \multicolumn{1}{c}{ Rata-rata } & 39,2 & 89,4 & 50,2 \\
\hline
\end{tabular}

Pada Tabel 2 dapat dilihat bahwa indikator ketercapaian kegiatan mengalami kenaikan dengan kenaikan rata-rata sekitar 50,2\%. Hal ini menunjukkan bahwa pengetahuan masyarakat tentang sampah dan permasalahannya serta pengelolaanya telah meningkat secara signifikan. Dengan peningkatan pengetahuan ini maka kesadaran masyarakat juga akan tumbuh bahwa pengelolaan sampah memerlukan partisipasi dari setiap warga.

\section{Kesimpulan}

Berdasarkan hasil dan pembahasan, maka dapat disimpulkan bahwa pengelolaan sampah secara terpadau berbasis lingkungan masyarakat dilokasi pengabdian dapat meningkatkan pengetahuan warga tentang sampah dan permasalahannya, jenis-jenis sampah, dan pengelolaan sampah berdasar partisipasi masyarakat meningkat meningkat 50,2\% setelah mengikuti kegiatan penyuluhan pengabdian masyarakat. Warga sudah mengetahui bahwa kegiatan pengelolaan sampah memerlukan partisipasi dari setiap warga yang dapat dimulai dari proses sederhana pemilahan sampah rumah tangga. Penggunaan konsep 3R (reuse, reduce, recycle) dapat menginspirasi warga untuk menjadikan sampah sebagai peluang untuk menambah pendapatan sekaligus menjaga lingkungan mereka sendiri.

\section{Acknowledgements}

Tim pengabdian mengucapkan terimakasih kepada Lembaga Penelitian dan Pengabdian Kepada Masyarakat (LPPM) Universitas Hamzanwadi yang telah memberikan izin kegiatan ini. Dan tim pengabdian mengucapkan terimakasih kepada semua pihak yang terlibat yaitu mitra pengabdian Kepala Desa Rumbuk beserta peragkat desa lainnya. Semoga dengan adanya kegiatan pengabdian yang dilakukan ini memberikan dampak positif dan perkembangan yang lebih baik kedepannya bagi warga Desa. 


\section{Daftar Referensi}

Affandy, N. A., Isnaini, E., \& Yulianti, C. H. (2015). Peran Serta Masyarakat Dalam Pengelolaan Lingkungan. Seminar Nasional Sains Dan Teknologi Terapan III 2015, 45.

Bukhari., \& Afrian., R. (2020). Edukasi Pengolahan Sampah Dusun Abadi

Kecamatan Birem Bayeun Aceh Timur. Global Science Society: Jurnal Ilmiah Pengabdian Kepada Masyarakat, 2(1), 279-285.

Dwiyanto, B. M. (2011). Model Peningkatan Partisipasi Masyarakat Dan

Penguatan Sinergi Dalam Pengelolaan Sampah Perkotaan *. Jurnal

Ekonomi Pembangunan: Kajian Masalah Ekonomi Dan Pembangunan, 12(2), 239. https://doi.org/10.23917/jep.v12i2.196

Maya, S., Haryono, S., \& Kholisya, U. (2018). Pemberdayaan Masyarakat Melalui Pengelolaan Sampah Menjadi Nilai Ekonomis dan Pembentukan Bank Sampah di Kelurahan Tanjung Barat. Proceeding of Community Development, 1(2017), 157. https://doi.org/10.30874/comdev.2017.21

Muryani, E., Widiarti, I. W., Savitri, N. D., Muryani, E., Widiarti, I. W., \& Savitri, N. D. (2020). Pembentukan Komunitas Pengelola Sampah Terpadu Berbasis masyarakat. JPPM UMP, 4(1), 117-124.

Olivia, D., Firmansyah, A., Hardjasaputera, H., \& Dian Mawarni, I. A. S. (2019). Pengelolaan Sampah Home Industry Berbasis Partisipatif Di Kelurahan Keranggan. Prosiding Konferensi Nasional Pengabdian Kepada Masyarakat Dan Corporate Social Responsibility (PKM-CSR), 2, 666-678. https://doi.org/10.37695/pkmcsr.v2i0.475

Sandika., I. K. B., Ekayana., A. A. G., \& Suryana., I. G. P. E. (2018). Edukasi Pengelolaan Sampah kepada Masyarakat di Desa Pecatu. Widyabhakti Jurnal Ilmiah Populer, I(1), 61-68.

Sulasminingsih., S., L., N., \& Marlina. (2020). Pengelolaan Sampah Mandiri Berbasis Masyarakat di Kelurahan Rangkapan Jaya Baru Kecamatan Pancoran Mas Kota Depok Sebagai Upaya Peningkatan Eekonomi Masyarakat Kelurahan Rangkapan Jaya Baru merupakan salah satu wilayah di Kecamatan Pancoran Mas Kota. Jurnal Bakti Masyarakat Indonesiaurnal, 3(1), 148-154.

Surya., A., \& Ariefahnoor., D. (2018). Pengelolaan dan Pengolahan Sampah

Pasar Desa Gudang Tengah Melalui Konsep 3R dan Teknologi Lingkungan. Jurnal Kacapuri, 1(1), 102-114.

Wardi, I. N. (2017). Kesehatan Lingkungan. Gadja Mada University Press, Yogyakarta. 177. 11(1), 167-177. 